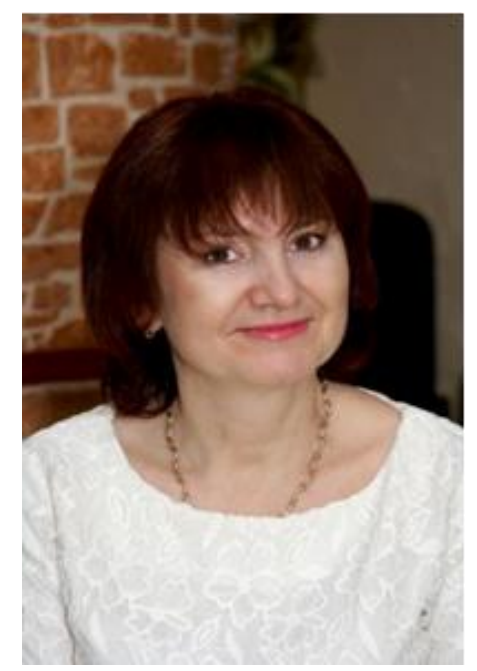

\section{KOTSUR \\ Halyna H., \\ archivy@ukr.net}

Ph.D., docent, Taras Shevchenko

National University of Kyiv

(Kyiv)

\title{
MILITARY ACTIVITY OF LAST KISH ATAMAN OF ZAPOROZ'KA SICH PETRO KALNYSHEVSKY IN TOTALITARIAN HISTORIOGRAPHY
}

The article shows that the Soviet, including Ukrainian Soviet historiography, developed contradictorily, had its own specificity, which was conditioned by the historical conditions of the time. During the Stalinist repressions, it lost its scientific functions, turned into an ideological maid of power. During the Brezhnev period, Ukrainian historiography was influenced by the negative effects of authoritarianism, the policies of total russification, the persecution of dissent. Diaspora historians have defended the national traditions of Ukrainian historiography. It was proved that the military activity of the Cossack ataman of Zaporoz'ka Sich P. Kalnyshevsky wasn't studied specifically, some pages of his biography were falsified or silenced. The Zaporozhian leader was mentioned in the context of the Russian-Turkish wars of the eighteenth century. The main purpose of the article is to reflect the issue of the military art of the Cossack ataman of Zaporoz'ka Sich P. Kalnyshevsky by the Soviet historiography during the time of totalitarianism. There are analyzed the features of the scientific works on this problem in the conditions of monopolization and sovietization of historiography, total introduction of the methodology of party and class interpretation of the historical process.

Key words: military activity, kish ataman, Petro Kalnyshevsky, Zaporoz'ka Sich, historiography.

\section{ВІДОБРАЖЕННЯ ВІЙСЬКОВОЇ ДІЯЛЬНОСТІ ОСТАННЬОГО}

КОШОВОГО ОТАМАНА ЗАПОРОЗЬКОЇ СІЧІ ПЕТРА

\section{КАЛНИШЕВСЬКОГО ІСТОРІОГРАФІЕЮ ТОТАЛІТАРНОЇ ДОБИ}

У статті відображено, що радянська, зокрема й украйнська радянська історіографія, розвивались суперечливо, мали свою специфіку, яка зумовлювалась тогочасними історичними умовами. В період сталінських 
репресій вона втратила свої наукові функиії, перетворилась в ідеологічну служницю влади. У добу брежснєвщини українська історіографія перебувала під впливом негативних наслідків авторитаризму, політики тотальної русифікаиії, переслідування інакомислення. Історики діаспори виступили на захист національних традииій української історіографії. Доведено, щьо військова діяльність кошового отамана Запорозької Січі П. Калнишевського спеціально не вивчалась, окремі сторінки його біографії фальсифікувались або замовчувались. Запорозький керманич бігло згадувався у контексті російськотуреиьких війн XVIII cm. Основна мета статті: з'ясувати висвітлення питання військового мистецтва кошового отамана Запорозької Січі П. Калнишевського радянською історіографією доби тоталітаризму. Проаналізовано особливості наукових праџь із даної проблематики в умовах монополізації та радянізації історіографії, тотального запровадження методології партійно-класового трактування історичного процесу.

Ключові слова: військова діяльність, кошовий отаман, Петро Калнитевський, Запорозька Січ, історіографія.

\section{ОТОБРАЖЕНИЕ ВОЕННОЙ ДЕЯТЕЛЬНОСТИ ПОСЛЕДНЕГО КОШЕВОГО АТАМАНА ЗАПОРОЖСКОЙ СЕЧИ ПЕТРА}

\section{КАЛНЫШЕВСКОГО ИСТОРИОГРАФИЕЙ ТОТАЛИТАРНОЙ ЭПОХИ}

В статье показано, что советская, в частности, украинская советская историография, развивались противоречиво, имели свою специфику, которая предопределялась тогдашними историческими условиями. В период сталинских репрессий историография потеряла свои научные функиии, превратилась в идеологическую служанку власти. В брежневские времена украинская историография находилась под воздействием негативных последствий авторитаризма, политики тотальной русификации, преследования инакомыслия. Историки диаспоры выступили на защиту национальных традииий украинской историографии. Доказано, что военная деятельность кошевого атамана Запорожской Сечи П. Калнышевского специально не изучалась, отдельные странищы его биографии фальсифицировались или замалчивались. О запорожском атамане бегло вспоминали в контексте русскотуреиких войн XVIII века. Основная цель статьи: выяснить освещение вопроса военного искусства кошевого атамана Запорожской Сечи П. Калнышевского советской историографией периода тоталитаризма. Проанализированы особенности научных трудов по данной проблематике в условиях монополизации и советизации историографии, тотального утверждения методологии партийно-классовой трактовки исторического процесса.

Ключевые слова: военная деятельность, кочевой атаман, Петр Калнышевский, Запорожская Сечь, историография. 
The process of national and cultural revival was stopped brutally in Soviet times, especially in the late 1920s and early 1930s, in Ukraine. It was required the «unity of thought» in the field of historical disciplines instead of objective researches, which were achieved by the defeat of scientific institutions and the prohibition of entire scientific fields, the elimination of the Ukrainian-language press. There were neglected elementarily the issues of the formation of Ukrainian statehood, the history of the Ukrainian Cossacks was distorted.

The Soviet, including Ukrainian Soviet historians, didn't pay attention to the participation of the kish ataman P. Kalnyshevsky in Russian-Turkish wars, and in particular his military art in the same context. Accordingly, during this period there was a small amount of works devoted to the Cossack leader. The reason should be seen in the establishment of ideological, censorship constraints and in the domination of the social aspect of the personal in the history. The person, the personality were moved to the last plan, while the society with division into categories was one of the first places. The emphasis was on the interests and antagonism of various social groups, while much less were studied the individual requests of a particular person.

It is possible to distinguish two historiographic stages, taking into account the peculiarities of the historical process of Soviet power, depending on the level of research on this topic: the first one - 20-30th years of the XX century, characterized by the lack of research of the military aspect of the history of the New Sich; the second - 40-80-ies of the XX century, marked by some progress in the study of this problem.

Already in the late 1920's there was an appeal to the military service of the Sich Cossacks, though in the context of studying the issues of socio-economic and political structure of Zaporizhzhia. Thus, in the scientific investigations of M. Slabchenko [26, p. 159-252] and M. Kyrychenko [16] is the information about the types of defensive structures of the Army Nyzove, designed to withstand the attack of the enemy: city-foburgs, beckett and military settlements. Historians note the existence of six such foburgs in the years of New Sich: Kodak, Perevalochna, 
Myshuryn Rig, Samar, Stone zaton, Romankovo. Beckets, whose purpose was to observe the movement of the Tatars and the Nogaiians, were located in the east and south in front of the cities-foburgs. M. Slabchenko observes that the indicated points did not provide reliable and timely protection of the Cossack liberties from the attacks of the enemy, given their small number and location far from each other: «The foburgs, obviously, were too small to be able to resist such influences... The Russian government strove its borders and line of defense as far forward as possible, while Sich, on the contrary, was pulling its limits to itself. The Zaporozhians sword was smaller than Russian ... The line of foburgs should either increase or strengthen. Sich chose the last. Strengthened the line of foburgs primarily through the so-called bekety, ...where guarded predominantly the appointed small Sich zalogs» [26, p. 170].

Fragmentary information about the military art of the Zaporozhian Cossacks of the times of Nova Sich (reconnaissance, tactics) was reflected in the article by O. Ryabinin-Skliarevsky published in 1927 by the historical section of the VUAN «The Zaporozhian revolts of the Dons Cossacks 1771-1774 and the beginning of the Zadunaysky Kish» [25, p. 65-83]. In the context of the disclosure of complex relationships between Zaporozhian Elders and ordinary Cossacks, the historian reveals their participation in the Don expeditions of 1771 and 1772.

On so-called times of «the decline of the Cossack army» [18, p. 225], its organization, weapons and «army in battle» [18, p. 288] is mentioned in the book by I. Krypyakevych «The History of the Ukrainian Army» [18], published in Lviv in 1936. First of all, the historian states the fact of the loss of the New Sich of its military position and its complete dependence on the Russian Empire. Accordingly, during the period of the Russian-Turkish wars of the eighteenth century, carrying out guerrilla raids and conducting operations on the Dnieper, «the Zaporozhians were unable to make trips independently» [18, p. 231].

From the 40's of the twentieth century the source base of the problem is enriched by publications of documents on the history of Russian-Turkish wars of the XVIII century [28], which are useful in clarifying the fighting functions of Cossacks 
during these events. The activation of researches on the history of martial arts of Sich Cossacks was promoted by the celebration of the 300th anniversary of the so-called «Reunification of Ukraine with Russia» and in this context the corresponding position of Soviet historiography.

Thus, in the early 1950's was published the first solid work of O. Apanovych [2] on the history of Ukraine from the sixteenth and eighteenth centuries, in which the military service of the Cossacks of the times of Nova Sich was set as a separate problem. The historian draws attention to the disclosure of such aspects as mobilization and manning, its tactics, armaments, and so on in the context of the study of the participation of the Zaporozhian Army in the Russian-Turkish war of 1735-1774. However, the time of writing has affected on the views of the author. The influence of Soviet ideology is clearly traced through the characterization by O. Apanovych the Zaporozhian Army as «one of the guns of the Russian feudal state in the accomplishment of the tasks of its internal and foreign policy» [2, p. 134]. The researcher emphasizes also that Russian military art had a beneficial effect on the Zaporozhian Army, since, «under the direct control of Rumyantsev and Suvorov, who in every way developed the specific qualities of Cossack troops and skillfully used them. Zaporozhian Cossacks improved their tactical receptions and improved individual sides of their military organization» [2, p. 109].

The historian covered the status of the Cossack Army, the absence of an age rating in the army, unlimited term nature of service, investigating the participation of Cossacks in the Russo-Turkish War of 1768-1774. It is noted that the manning of the Army Nyzove was very slow before the campaigns, which, according to the author, were the reason for the massive evasion of the wealthy Cossacks from the service and the sending of hired laborers instead of them.

In terms of the characteristics of the Army Nyzove as a combat unit, O. Apanovych divides it into a cavalry and infantry, in which is dedicated a special place to the Zaporozhian cavalry, since it was only the Cossack who could provide himself with a horse. So, going on a campaign, «a proper Cossack» was supposed to 
have two horses, while «the military officer acted on a campaign with 16 horses, a colonel with eight, and a regimental commander with three horses» [2, p. 120].

Attention is drawn in this study to the strategic features of the Cossacks military art: blows from the flanks and the rear, the use of the reserve, the creation of ambushes, the use of such kind of combat activity as «searches». It is stated the priority of their avant-garde, reconnaissance and outpost border guard service during the protection of Russian borders during the XVIII century.

In general, O. Apanovych points to the unity of the «two fraternal peoples», which corresponded to the Marxist-Leninist methodology of that time, as well as other contemporary Soviet historians, assessing the actions of the Russian and Zaporozhian Army in the Russian-Turkish wars of the designated time. Of course, in such lines is difficult not to notice the idealization of the relationship between the two military forces. As we know from the documents, the Cossacks suffered repeatedly from the tyranny of representatives of the Russian army. Therefore, there is no reason to talk about any «unity». A joint study by K. Huslysty and O. Apanovych «Zaporoz'ka Sich and its progressive role in the history of the Ukrainian people» [11] expands information about the participation of Zaporozhians under the leadership of P. Kalnyshevsky in the Russian-Turkish war of 1768-1774. The authors reflect the key aspects of tactical maneuvers of the Cossacks in the Russian army. It is analyzed the blocking of hostile castles by Cossacks as a way of diverting significant forces from the main theater of combat operations and intelligence activities. It is emphasized the role of the Cossack army in the combat cover of the main forces. The place of the last kish ataman P. Kalnyshevsky was not reflected in the events under consideration, looking at the methodology of the study, along with the characterization of the Cossacks' combatants as part of the Russian Army.

The monograph of O. Apanovych «The armed forces of Ukraine in the first half of the XVIII century» [3] is devoted to the participation of Zaporozhians in the Russian-Turkish war of the first half of the existence of the New Sich. The book, like the previous publications of the historian, has a number of shortcomings. The reason for this is seen in the use of the information material of $O$. Apanovych previous 
article when it was written about the war of the second half of the XVIII century, without taking into account the essential differences and features that existed in the conduct of hostilities during the war of 1735-1739. In addition, O. Apanovych used also during the preparation of the monograph the archival material covering the military events of the second half of the XVIII century and in no way connected with the events of the 1930's. Considerable attention is paid by the historian on the analysis of the relations between the Cossack army and the Russian army as military units. It is noted that during the military operations «kish ataman was a subject of the Russian commander-in-chief» [3, p. 104]. «The leadership of the Russian command was limited only in strategic tasks» [3, p. 105], and the tactical actions of the Cossacks were solved more often on their own, but the dependency outraged Zaporozhians. It caused protests, discontent, and even cases the disobedience. The text even used the sentence, which stated that «Russian officers highly assessed the combat power and military skills of the Zaporozhian Army. The text used even the sentence, which stated that «Russian officers assessed highly the combat power and military skills of the Zaporozhian Army. They even sought to enter the kurens as honorary members» [3, p. 125]. However, it does not have factual and documentary confirmation such a desire from the part of Russian officers in the first military campaign, while this was pronounced attitude towards the Cossacks from the side of representatives of the Russian leadership in the second Russian-Turkish war.

The study of a wide range of archival materials, literature, published sources allowed O. Apanovych to carry out an analysis of the socio-economic aspect of the Russian-Turkish war, to observe the dependence of the structure and material and technical provision of the Cossack armed forces on the level of economic development of the Cossack economy and the differentiation of the Cossacks as a state.

Russian historians, studying the armed forces of the Russian army and their participation in the Russian-Turkish wars, didn't mention the participation of Cossacks in it, or gave them a minor, secondary role. Thus, Yu. Klokman calls in his work «Field Marshal Rumyantsev during the Russian-Turkish War of 1768-1774» 
[17] the duties of the Cossacks were only defensive functions, noting that «Zaporozhian Cossacks were supposed to carry on their boats attacks on enemy of vessels located above Silistriya, and not to let them go further on this fortress» $[17$, p. 134].

In turn, O. Druzhynina [12] argues that the situation of the Zaporozhian Cossacks was better than other Ukrainian Cossack detachments during the war. It was explained by such reasons as the need for the Cossack service and the fear of Russian leadership against the possibility of the Zaporozhians moving to the enemy's side. To keep the Zaporozhians under their authority, according to the author, Russian nobles made a thoughtful political step. They signed up to Zaporozhian Kurens in order to demonstrate their commitment. We find the names of P. Panin, H. Potiomkin, O. Prozorovsky among them [12, p. 36].

We found thementions of the participation of the Army Nyzove in the RussoTurkish War during the New Sich times in the works of R. Peresvietov [22], S. Solovyov [27], L. Bezkrovny [6], N. Poliovy [23], Kh. Kachalov [15], H. Nekrasov [21].

The collective publication of the ten-volume «History of the Ukrainian SSR» [14] took a certain niche in the historiography of the Zaporozhians' military art in the period under investigation. There is given the information on the Russian-Turkish wars of the XVIII century in the third volume, published in 1970. The assessment of the fighting of Zaporozhian Cossacks is devoid of a clearly defined character and is filed fragmentarily, based on the coverage of the military actions of the Russian army. If the reference to the Cossacks was minimized during the first war, then considering the military campaign of 1768-1774, much more attention was paid to the combat raids of the Cossacks. The activity of the Zaporozhian Cossacks was masked under military raids and the merits of the Russian-Ukrainian army, which doesn't allow to recreate the place of the Army Nyzove at the events of that time.

In the second half of the twentieth century appeared the specialized researches of military activity of the Zaporozhian Cossacks. So, V. Fomenko, as one of the first, explored the plan of the Zaporozhian shipyard [29]. Despite the fact that it was 
repeatedly mentioned in historical sources and in special military-engineering studies, the plan of the Zaporizhzhia shipyard hasn't previously been the subject of historical research, which makes this article even more important from a scientific point of view.

Noteworthy are also the articles by $\mathrm{O}$. Apanovych [4; 5], published in the late 80 's - early 90's of the twentieth century. Although they have been given little space to the XVIII century military affairs, their value is to outline (as opposed to its previous publications) the role of the Zaporozhian troops during the Russo-Turkish wars, which conducted rigorous combat raids both on land and on waterways. It is necessary to include the collective work of Yu. Mytsyk, S. Plokhiy and I. Storozhenko [20] dedicated to the Ukrainian Cossacks to this period.

The specificity of the development of historical science in this period predetermined the priority of the socio-economic aspect of the study of the history of Zaporoz'ka Sich. The emphasis was placed on the «class struggle» that existed among the Cossacks, first and foremost, in the confrontation between the elders and the simple Cossacks. As a result, monographs are dominated by the negative coverage of the elders in general, as well as kish ataman P. Kalnyshevsky, in particular.

On the background of research on socio-economic relations in the Sich, it was highlighted the issue of the participation of P. Kalnyshevsky in suppressing the Haydamak movement. One of the first highlighted this aspect V. Hrekov in the articles published on the pages of «Ukraine», entitled «Zaporozhian Kish and Koliyivschyna» [10]. According to the historian, the Zaporozhian elders sympathized with the Haidamaks, providing secret assistance to the rebel. P. Kalnyshevsky, being the chief ataman, personally allowed the Cossack poor to go to Poland to try to help the Ukrainian people in the struggle with the Polish gentry for their civil rights and for religion. D. Kulynyak holds the same point of view. He believes that P. Kalnyshevsky, being the kish ataman, was forced to perform imperial orders [19].

A typical example of the embodiment of Soviet ideology in historical science was the work of V. Holobutsky «Zaporoz'ka Sich in the last years of his existence» 
[8], in which P. Kalnyshevsky is presented as an omnipotent ruler with oligarchic inclinations, destroying the democratic traditions of the Zaporoz'ka Sich. P. Kalnyshevsky «was one of the initiators of the decision, which envisioned the strengthening of the power of the elders over the Cossacks and the expansion of its powers. This decree, in particular, provided for the right of the elder to punish anyone who tried to commit a violation of the established order in the Sich or to express disobedience to the leadership of Kish» [8, p. 96-97]. The decision of the ruling is considered by the historian as one of the key reasons for the long-term stay of P. Kalnyshevsky in the post of kish ataman. Covering the participation of the Cossacks in the Russian-Turkish war of 1769-1774 concerns mainly the preparation for military activities and its defense activities. The researcher is at the opinion that the participation of Cossacks in the war significantly limited the Cossack selfgovernment in the Sich. V. Holobutsky notes that preparations for the war began by the Cossacks in the autumn of 1768 , justifying this by the instructions of the military chancellery on November 13, 1768, in which it was stated that the owners of winterers should equip their servants in case of the appearance of the enemy. What about the rest of the Cossacks, they need to have two horses and a gun. The given number of Cossack detachments in the Russian army at the beginning of the war complements factual the picture. It is reported that «at the end of September 1769, 7,400 Cossacks, headed by P. Kalnyshevsky, departed to the Bug to guard the border from Orlyk and Hard to the Mertvi Vody River. The second part of 2200 Cossacks descended along the Dnipro River in 38 ships» [8, p. 107]. According to V. Holobutsky, Zaporoz'ka Sich sent about 11,000 soldiers to the Russian army. According to the author, this situation was used by the Crimean Khan, who broke with his army the defense of the corps of General von Berg and plunged into the territory of Zaporizhzhia.

V. Holobutsky calls the Zaporozhian army in his study «Zaporozhian Cossacks» [7], as one of the most trained military units in the structure of the striking forces of the Russian army. Zaporozhians showed incredible courage and heroism during the Russo-Turkish wars [7, p. 379-380; 8, p. 512]. Brief information about the military 
merits of P. Kalnyshevsky contained in the writings of the Soviet researcher H. Frumenkov [30].

The problem of the participation of P. Kalnyshevsky in Russian-Turkish wars was not adequately covered in the works of the Ukrainian diaspora historians. It was obviously due to the lack of access to the sources and scientific literature. An indication of this is "the request of B. Bidnov in a letter to D. Yavornytsky to send at least an instance of «Sources on the history of Zaporozhian Cossacks» [1, p. 31-32]. Being outside the Soviet political regime, Ukrainian diaspora scholars were free of ideological canons and methodological dogmas inherent in the period of the USSR's existence, but didn't have the opportunity to objectively study the history of the Cossacks in connection with the lack of access to historical sources.

Consequently, the analysis of the Soviet historiography of the problem shows that the development of historical thought was controversial, specifically, due to specific historical conditions. Soviet historians were captured by Stalinist stereotypes, Marxist-Leninist ideology, falsification of events and facts, and the intervention of the Communist Party structures in defining the subjects of research.

At this time appeared separate works about the Cossacks as a military force and the study of the military service of the Zaporozhian Cossacks in the Russian-Turkish wars of the XVIII century. The introduction of a new archival material for scientific circulation served to expand the subject field of the problem at this stage. Historians reveal along with the ideological estimates of the Zaporozhian army as a secondary component of the Russian army, at the same time, the concrete facts of military activity of the Cossacks in the second half of the XVIII century, emphasized the key aspects of their strategy and tactical maneuvers.

Along with the coverage of the military activities of the Zaporozhians of the Pidpil'nens'ka Sich, historiographical analysis proves the absence of works that would be directly dedicated to the military skill of the last kish ataman. For the most part, the figure of P. Kalnyshevsky is assessed negatively, mainly in the context of considering his place in the current political events. The military aspect of his activities, in fact, fell out of sight of historians. The reason for this should be seen not 
only in the priorities of the Soviet, including the Ukrainian Soviet historiography, the establishment of censorial restrictions, but also in the theoretical and methodological principles of the development of contemporary historical science.

Under the conditions, when historic science became in the Ukrainian SSR a servant of the anti-Ukrainian regime, the research centers of the Ukrainian diaspora focused on those most important studies of the history of Ukraine, that were falsified or suppressed by Soviet historiography.

\section{List of Literature}

1. Абросимова С. Наукові розвідки Василя Біднова. Козацтво. 1996. № 1(4). C. 31-32.

2. Апанович О. Запорозьке військо як складова частина російської армії в другій половині XVIII ст. Наукові записки інституту історії АН УРСР. Київ, 1953. Т. 5. С. 109-136.

3. Апанович О. Збройні сили України першої половини XVIII ст. Київ, 1969. $228 \mathrm{c}$.

4. Апанович О. Козацька республіка. Пам'ятки України. 1989. № 3. С. $22-$ 27.

5. Апанович О. Не пропала їхня слава. Вітчизна. 1990. № 9. С. 164-173.

6. Безкровный Л. Г. Русская армия и флот в XVIII веке: очерки. Москва, $1958.644 \mathrm{c}$.

7. Голобуцкий В. Запорожское казачество. Киев, 1957. 461 с.

8. Голобуцький В. Запорізька Січ в останні часи свого існування. 1734-1775. Київ, 1961. 415 с.

9. Голобуцький В. Запорозьке козацтво. Київ, 1994. 539 с.

10. Греков В. Запорозький Кіш та Коліївщина. Україна. 1928. Кн. 4. С. 14 20.

11. Гуслистий К., Апанович О. Запорозька Січ та її прогресивна роль в історії українського народу. Київ, 1954. 87 с.

12. Дружинина Е. Кючук-Кайнарджийский мир. 1774 г. (его подготовка и заключение). Москва, 1955. 384 с.

13. Загорулько Б., Печенізький В. Та й побратались Соколи... Жовтень. 1970. № 7-8. C. 132-143.

14. История Украинской ССР : в 10-ти т. / редкол. : Г. Сергиенко, В. Борисенко, В. Маркина и др. ; глав. ред. Ю. Кондуфор. Киев, 1983. Т. 3 : Освободительная война и воссоединение Украины с Россией. Начало разложения феодализма и зарождение капиталистических отношений (вторая половина XVII-XVIII в.). 719 с.

15. Качалов Х., Носов И., Сорокин И. Морская пехота. Москва, 1957. 109 с.

16. Кириченко М. Соціально-політичний устрій Запоріжжя (XVIII сторіччя). Харків, 1931. 177 с. 
17. Клокман Ю. Фельдмаршал Румянцев в период русско-турецкой войны 1768-1774 гг. Москва, 1951. 206 с.

18. Крип'якевич I. Історія українського війська : в 2 ч. Репр. вид. 1936 р. Київ, 1993. Ч. 1. 289 с.

19. Кулиняк Д. Соловецький в'язень, або Останній гетьман України (До 300річчя від дня народження Петра Калнишевського). Дніпро. 1990. № 7. С. 137151.

20. Мицик Ю., Плохій С., Стороженко I. Як козаки воювали. Дніпропетровськ, 1990. 301 с.

21. Некрасов Г. Роль России в Европейской международной политике. 17251739 гг. Москва, 1976. $317 \mathrm{c.}$

22. Пересветов Р. Тайны выцветших строк. Москва, 1963. 287 с.

23. Полевой Н. Польская и турецкая войны, в царствование императрицы Анны Іоановны. Вырезка. Б. г. Т. 14. Отд. 3. С. 37-88.

24. Румянцев П. Докумены : в 3 т. Москва, 1952. Т. 2. 864 с.

25. Рябінін-Скляревський О. Запорізькі бунти дунайців 1771-1774 pp. і початок Задунайського Коша. Записки украйнського наукового товариства в Києві Київ, 1927. Т. 26: Науковий збірник історичної секції / під ред. М. Грушевського. С. 65-83.

26. Слабченко М. Паланкова організація Запорозьких Вольностів. Праці для виучування західно-руського та украӥнського права. Київ, 1929. Вип. 6. С. 159252.

27. Соловьев С. История России с древнейших времен : в 15 кн. Москва, 1963. Кн. 10. Т. 19.780 с.

28. Суворов А. Документы : в 4 т. / под. ред. Г. Мещерякова. Москва, 1949. T. $1.789 \mathrm{c}$.

29. Фоменко В. План Запорозької верфі. Архіви України. 1969. № 3-4. С. 4952.

30. Фруменков Г. Узники Соловецкого монастыря. Архангельск, 1979. 223 с.

\section{References}

1. Abrosymova, S. (1996). Naukovi rozvidky Vasylia Bidnova [Scientific Investigation of Vasyl Bidnov]. Kozatstvo [Cossacks]. 1 (4). 31-32. [in Ukrainian].

2. Apanovych, O. (1953). Zaporozke viisko yak skladova chastyna rosiiskoi armii $v$ druhii polovyni XVIII st. [Zaporozhian Army as a Part of the Russian Army in the Second Half of the XVIII Century]. Naukovi zapysky instytutu istorii [Scientific Notes of the Institute of History]. Kyiv. 5. 109-136. [in Ukrainian].

3. Apanovych, O. (1969). Zbroini syly Ukrainy pershoi polovyny KhVIII st. [The Armed Forces of Ukraine in the First Half of the XVIII Century]. Kyiv. 228. [in Ukrainian].

4. Apanovych, O. (1989). Kozatska respublika [The Cossack Republic]. Pam'iatky Ukrainy [Sights of Ukraine]. 3. 22-27. [in Ukrainian].

5. Apanovych, O. (1990). Ne propala yikhnia slava [Their Glory didn't Disappear]. Vitchyzna [Homeland]. 9. 164-173. [in Ukrainian]. 
6. Bezkrovnyj, L.G. (1958). Russkaja armija i flot v XVIII veke : ocherki [Russian Army and Navy in the XVIII Century : essays). Moskow. 644. [in Russian].

7. Golobuckij, V. (1957). Zaporozhskoe kazachestvo [Zaporozhian Cossacks]. Kyiv. 461. [in Russian].

8. Holobutskyi, V. (1961). Zaporizka Sich v ostanni chasy svoho isnuvannia. 1734-1775 [Zaporozhian Sich in the Last Times of its Existence. 1734-1775]. Kyiv. 415. [in Ukrainian].

9. Holobutskyi, V. (1994). Zaporozke kozatstvo[Zaporozhian Cossacks]. Kyiv. 539. [in Ukrainian].

10. Hrekov, V. (1928). Zaporozkyi Kish ta Koliivshchyna [Zaporozhian Kish and Koliyivschyna]. Ukraina [Ukraine]. 4.14 - 20. [in Ukrainian].

11. Huslystyi, K. and Apanovych, O. (1954). Zaporozka Sich ta yii prohresyvna rol $v$ istorii ukrainskoho narodu [Zaporoz'ka Sich and its Progressive Role in the History of the Ukrainian People]. Kyiv. 87. [in Ukrainian].

12. Druzhinina, E. (1955). Kjuchuk-Kajnardzhijskij mir. 1774 g. (ego podgotovka $i$ zakljuchenie) [Kiuchuk-Kaynardzhyysky Peace. 1774 (its preparation and conclusion)]. Moskow. 384. [in Russian].

13. Zahorulko, B., Pechenizkyi, V. (1970). Ta y pobratalys Sokoly... [And Falcons Made Friends...]. Zhovten. [October]. 7-8. 132-143. [in Ukrainian].

14. Kondufor, Ju., Sergienko, G., Borisenko, V., Markina, V. and Mel'nik, L. eds. et al. (1983). Istorija Ukrainskoj SSR [History of the Ukrainian SSR] : v $10 \mathrm{t}$. Osvoboditel'naja vojna $i$ vossoedinenie Ukrainy s Rossiej. Nachalo razlozhenija feodalizma $i$ zarozhdenie kapitalisticheskih otnoshenij (vtoraja polovina XVII $X V I I I$ v.) : in $10 \mathrm{vol}$. [The Liberation War and the Reunification of Ukraine with Russia. The Beginning of the Disintegration of Feudalism and the Birth of Capitalist Relations (Second Half of the XVII - XVIII Centuries)]. Kyiv. 3. 719. [in Russian].

15. Kachalov, H., Nosov, I. and Sorokin, I. (1957). Morskaja pehota [Marine Foot Army]. Moskow. 109. [in Russian].

16. Kyrychenko, M. (1931). Sotsialno-politychnyi ustrii Zaporizhzhia (XVIII storichchia) [Socio-Political Structure of Zaporizhzhia (XVIII Century)]. Kharkiv. 177. [in Ukrainian].

17. Klokman, Ju. (1951). Fel'dmarshal Rumjancev v period russko-tureckoj vojny 1768 -1774 gg. [Field Marshal Rumyantsev during the Russian-Turkish War of 1768-1774]. Moskow. 206. [in Russian].

18. Kryp'iakevych, I. (1993). Istoriia ukrainskoho viiska [History of the Ukrainian Army] : v 2 ch. Repr. vyd. 1936 r. Kyiv. 1. 289. [in Ukrainian].

19. Kulyniak, D. (1990). Solovetskyi v'iazen, abo Ostannii hetman Ukrainy (Do 300-richchia vid dnia narodzhennia Petra Kalnyshevskoho) [Solovetsky Prisoner, or 
the Last Hetman of Ukraine (To the 300th Anniversary of the Birthday of Petro Kalnyshevsky)]. Dnipro [Dnipro]. 7. 137-151. [in Ukrainian].

20. Mytsyk, Yu., Plokhii, S. and Storozhenko, I. (1990). Yak kozaky voiuvaly [How did Cossacks Fight]. Dnipropetrovsk. 301. [in Ukrainian].

21. Nekrasov, G. (1976). Rol' Rossii v Evropejskoj mezhdunarodnoj politike. 1725-1739 gg. [The Role of Russia in European International Politics. 1725-1739]. Moskow. 317. [in Russian].

22. Peresvetov, R. (1963). Tajny vycvetshih strok [Secrets of the Faded Lines]. Moskow. 287. [in Russian].

23. Polevoj, N. Pol'skaja i tureckaja vojny, v carstvovanie imperatricy Anny Ioanovny [The Polish and Turkish Wars, in the Reign of Empress Anna Ivanovna]. Vyrezka. Bez goda. 14, 3. 37-88. [in Russian].

24. Rumjancev, P. (1952). Dokumeny [Dokuments] : v 3 t. Moskow. 2. 864. [in Russian].

25. Riabinin-Skliarevskyi, O. (1927). Zaporizki bunty dunaitsiv 1771-1774 rr. i pochatok Zadunaiskoho Kosha [Zaporozhian Revolts of the Don Cossacks in 17711774 and the Beginning of the Zadunaysky Kish]. Naukovyi zbirnyk istorychnoi sektsii : Zapysky ukrainskoho naukovoho tovarystva v Kyievi [Scientific Collection of the Historical Section : Notes of the Ukrainian Scientific Society in Kiev] / pid red. holovy sektsii akad. M. Hrushevskoho. Kyiv. 26. 65-83. [in Ukrainian].

26. Slabchenko, M. (1929). Palankova orhanizatsiia Zaporozkykh Volnostiv [Palanka's Organization of Zaporozhian Liberties]. Pratsi dlia vyuchuvannia zakhidno-ruskoho ta ukrainskoho prava [Works for the Study of Western-Russian and Ukrainian Law]. Kyiv. 6. 159-252. [in Ukrainian].

27. Solov'ev, S. (1963). Istorija Rossii s drevnejshih vremen [History of Russia from the Earliest Times] : v $15 \mathrm{kn}$. Moscow. 10, 19. 780. [in Russian].

28. Meshherjakov, G. (1949). Suvorov, A. Dokumenty [Documents]: v 4 t. Moscow. 1. 789. [in Russian].

29. Fomenko, V. (1969). Plan Zaporozkoi verfi [The Plan of the Zaporozhian Shipyard]. Arkhivy Ukrainy [Archives of Ukraine]. 3-4. 49-52. [in Ukrainian].

30. Frumenkov, G. (1979). Uzniki Soloveckogo monastyrja [Prisoners of the Solovetsky Monastery]. Arkhangelsk, 223. [in Russian].

\section{Reviewer:}

Irina Borodai, Doctor of History, Professor

Received: 06/12/2018 